\title{
Changes in serum testosterone concentrations in the male pig during development
}

\author{
B. Colenbrander, F. H. de Jong* and C. J. G. Wensing \\ Department of Functional Morphology, State University Utrecht, Bekkerstraat 141, Utrecht, and \\ * Department of Biochemistry, Division of Chemical Endocrinology, Erasmus University Rotterdam, \\ Rotterdam, The Netherlands
}

\begin{abstract}
Summary. Serum testosterone concentrations were elevated between 40 and 60 days p.c. but were low between 60 and 100 days p.c. when the testis descends. Elevated concentrations occurred in the perinatal period and from the 18 th week after birth. Between 60 days p.c. and 16 weeks after birth the changes in serum testosterone concentrations parallel those of testicular development, as determined by morphology and steroid histochemistry, and peripheral LH concentrations.
\end{abstract}

\section{Introduction}

It is generally accepted that, in the testis, the interstitial (Leydig) cells are the principal source of the steroid hormone testosterone (Cooke, de Jong, van der Molen \& Rommerts, 1972). In the pig these cells show a high degree of differentiation during three phases of life. The first phase is in the early fetal period during gonadal differentiation; the second phase is in the perinatal period; the third phase extends from puberty onwards (Allen, 1904; Moon \& Hardy, 1973; van Straaten \& Wensing, 1977). In each of these phases the testis shows marked positive hydroxysteroid dehydrogenase reactions (Moon \& Raeside, 1972; Wrobel, Schilling \& Dierichs, 1973; van Straaten \& Wensing, 1978). In the pig (Booth, 1975), as in many other mammalian species (Attal, 1969; Resko, Feder \& Goy, 1968; Challis, Kim, Naftolin, Judd, Yen \& Benirschke, 1974), testosterone is one of the principal steroids produced in the fetal period. In the adult boar testosterone secretion appears to be quantitatively unimportant and the main androgens present in the blood are $\mathrm{C}_{19}$-16-unsaturated steroids (Gower, 1972; Ruokonen \& Vihko, 1974; Booth, 1975). Nevertheless, the relatively small amount of testosterone present in the serum could be used as an indicator of testicular activity.

In the present investigation the concentrations of serum testosterone in male pigs during fetal and postnatal life were studied. The aim was to correlate these data with morphological and histochemical studies of the testis and with changes in serum LH concentrations and so lead to a better understanding of the development and function of the hypothalamo-hypophysial-gonadal system in this species.

\section{Materials and Methods}

\section{Animals}

The animals were all crossbred Dutch Landrace $\times$ Yorkshire. Blood samples were collected from 111 fetal male pigs ranging in age from 40 to 117 days post coitum. Samples were collected from the umbilical artery at laparotomy and hysterotomy of anaesthetized or slaughtered sows. Single blood samples were obtained from 38 boars aged between 0 and 5 weeks after birth. A further 8 males were used to obtain serial blood samples at approximately 2 week intervals between 6 and 25 weeks after birth. The blood samples from the postnatal pigs were taken from the jugular vein. Serum was stored at $-20^{\circ} \mathrm{C}$ until assay. 


\section{Hormone determinations}

Testosterone concentrations were determined by radioimmunoassay, using the antiserum and procedure described by Verjans, Cooke, de Jong, de Jong \& van der Molen (1973). Samples were assayed in duplicate, using two different volumes of plasma ( 250 and $500 \mu \mathrm{l}$ for the fetal and juvenile period, 100 and $200 \mu \mathrm{l}$ for the perinatal and pubertal period). Testosterone was separated from $5 \alpha-$ dihydrotestosterone, which has a $50 \%$ cross-reaction with the antiserum, by chromatography on microcolumns of alumina (Verjans et al., 1973) or Sephadex LH-20 (cyclohexane: methanol: ethyl acetate, $75 / 12 \cdot 5 / 12 \cdot 5$, by vol.). The sensitivity of the method was $20 \mathrm{pg} / \mathrm{sample}$. Intra-assay variance, as calculated from the differences between the results of duplicate determinations, varied between $0 \cdot 14$ and $1.19 \mathrm{ng} / \mathrm{ml}$, depending on the concentration in the sample (0-1 and $8-15 \mathrm{ng} / \mathrm{ml}$, respectively). The interassay variance was $12.9 \%$ (coefficient of variation) at the level of $100 \mathrm{pg}$ testosterone measured.

Analysis of variance of serum testosterone values for groups of animals at various ages was used to detect statistical differences.

\section{Results}

The results are plotted in Text-fig. 1. Serum testosterone concentrations were elevated from 40 until 60 days post coitum and averaged $0.47 \pm 0.31$ (s.d.) $\mathrm{ng} / \mathrm{ml}$, excluding the single high value at 58 days p.c. From 60 until 100 days post coitum serum testosterone concentrations were significantly lower $(0.15 \pm 0.08 \mathrm{ng} / \mathrm{ml}, P<0.05)$ than those between 40 and 60 days p.c. In the perinatal period serum testosterone concentrations rose, the highest concentrations occurring in the 2 nd and $3 \mathrm{rd}$ week after birth $(1.30 \pm 0.38 \mathrm{ng} / \mathrm{ml})$ and declining thereafter $(P<0.05)$. The serum testosterone concentrations then remained relatively low $(0.47 \pm 0.40 \mathrm{ng} / \mathrm{ml})$, with only occasional high values, until the 18 th week of age when they rose significantly $(1.77 \pm 0.96 \mathrm{ng} / \mathrm{ml} ; P<0.05)$.

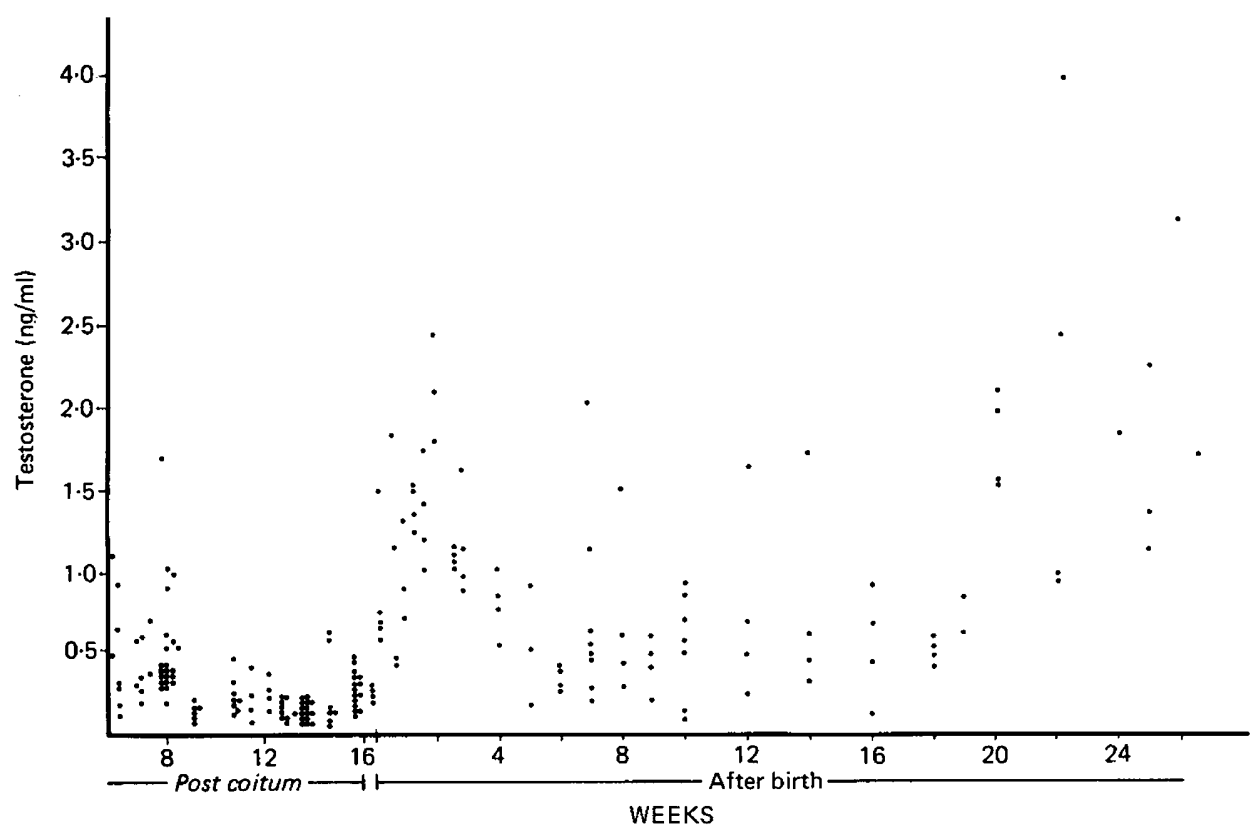

Text-fig. 1. Serum testosterone concentrations in male pigs from 40 days post coitum to 25 weeks of age. 


\section{Discussion}

In the fetal pig the Leydig cells show a high degree of differentiation between 35 and 40 days post coitum (Moon \& Hardy, 1973). In this same period testicular testosterone concentrations are elevated (Raeside \& Sigman, 1975) and testosterone secretion by testicular tissue in vitro is enhanced (Stewart \& Raeside, 1976). In the 7th week post coitum the testis displays a morphological regression (Moon \& Hardy, 1973) and a diminished biochemical activity (Raeside \& Sigman, 1975; Stewart \& Raeside, 1976). Our results show that serum testosterone concentrations remain elevated until the end of the 2nd month p.c. and decline thereafter, probably in parallel with the morphological and biochemical changes, although these are not extensively documented. Although we obtained some high values about 57 days p.c. the peak in serum testosterone concentrations reported by Meusy-Dessolle (1974) could not be detected.

The principal function of the elevated concentrations of serum testosterone in the second month after conception is most likely to be the differentiation of the male genital tract and the sexual differentiation of centres in the central nervous system (Dörner, 1976). Morphological differentiation of the genital apparatus in the pig takes place between 28 and 55 days p.c. (Koning, 1942; Marrable, 1971). Brain sex differentiation occurs in many species, and probably also in the pig, just after the morphological differentiation of the genital apparatus (Dörner, 1976).

Gubernacular development and subsequent testicular descent usually occur in the pig between 65 and 85 days post coitum, and the low serum testosterone levels and the reduced steroid-histochemical activity of the testis (van Straaten \& Wensing, 1978) at this time support the postulate that testicular descent is not dependent on increased concentrations of testosterone in the peripheral circulation (Wensing, 1973).

The rise of serum testosterone concentrations in the perinatal period until the 2 nd and 3 rd week after birth and the subsequent decline are comparable with the changes known to occur with age in the testosterone concentration (Booth, 1975; Segal \& Raeside, 1975), the steroid-histochemical activity (Wrobel et al., 1973; van Straaten \& Wensing, 1978) and the morphological differentiation (Dierichs, Wrobel \& Schilling, 1973; van Straaten \& Wensing, 1977) of the testis. All these changes are probably related directly to serum LH concentrations (Colenbrander, Kruip, Dieleman \& Wensing, 1977) which show a comparable pattern but are earlier.

The significance of the increased testicular activity during the perinatal period remains obscure. The decline of serum testosterone concentrations after the 3rd post-natal week may be due to the maturation of the hypothalamo-hypophysial-gonadal feedback system. That this feedback system does not operate in the immediate neonatal period is indicated by the observations that neonatal serum testosterone concentrations rise in parallel with the increasing serum LH concentrations (Colenbrander et al., 1977). Castration in the pig at 8 weeks of age causes an increase in serum LH concentrations (Colenbrander et al., 1977). It might therefore be concluded that the hypothalamohypophysial-gonadal feedback system starts to operate before 8 weeks after birth, and most probably in the 2 nd or 3 rd week of life.

The decrease and generally low concentrations of serum testosterone after the 3rd post-natal week parallel the changes in testicular testosterone concentrations reported by Elsaesser, König \& Smidt (1972). The increase of serum testosterone after 18 weeks of age is correlated with increased morphological differentiation and steroid histochemical activity in the testis (Wrobel et al., 1973; van Straaten \& Wensing, 1978), and appears at an earlier stage than that reported by Meusy-Dessolle (1975). Testicular testosterone concentrations remain low (Ruokonen \& Vihko, 1974; Booth, 1975), but there is probably enhanced testosterone production because the percentage of Leydig cells in the whole testis is diminished as the tubular component increases (van Straaten \& Wensing, 1977).

We thank Mrs H. B. W. Clotscher-Rooseboom, Mrs C. M. J. E. van Rossum-Kok and Mr H. G. Bierings for technical assistance. 


\section{References}

AlLEN, B.M. (1904) The embryonic development of the ovary and testis of the mammals. Am.J. Anat. 3, 89146.

ATTAL, J. (1969) Levels of testosterone, androstenedione estrone and estradiol-17 $\beta$ in the test is of fetal sheep. Endocrinology 85, 280-289.

Booth, W.D. (1975) Changes with age in the occurrence of C-19 steroids in the testis and submaxillary gland of the boar. J. Reprod. Fert. 42, 459-472.

Challis, J.R.G., Kim, C.K., Naftolin, F., Judd, H.L., Yen, S.S.C. \& Benirschke, K. (1974) The concentration of androgens, oestrogens, progesterone and luteinizing hormone in the serum of foetal calves throughout the course of gestation.J. Endocr.60, 107115.

Colenbrander, B., Kruip, Th.A.M., Dieleman, S.J. \& Wensing, C.J.G. (1977) Changes in serum LH concentrations during normal and abnormal sexual development in the pig. Biol. Reprod. 17, 506-513.

CoOKe, B.A., de Jong, F.H., van der Molen, H.J. \& ROMMERTS, F.F.G. (1972) Endogenous testosterone concentrations in rat testis interstitial tissue and seminiferous tubules during in vitro incubation. Nature, New Biol. 237, 255-256.

Dierichs, R., Wrobel, K.H. \& SChILling, E. (1973) Licht- und elektronen-mikroskopische Untersuchungen an den Leydigzellen des Schweines während der postnatalen Entwicklung. Z. Zellforsch. mikrosk. Anat. 143, 207-227.

DörNer, G. (1976) Sex hormone-dependent differentiation processes. In Hormones and Brain Differentiation, pp. 94-127. Ed. G. Dörner, Elsevier, Amsterdam.

Elsaesser, F., König, A. \& SMidt, D. (1972) Der Testosteron und Androstendion Gehalt am Eberhoden in Abhängigkeit vom Alter. Acta endocr., Copenh. 69, 553-566.

Gower, D.B. (1972) 16-Unsaturated C-19 steroids. A review of their chemistry, biochemistry and possible physiological role. J. Steroid Biochem. 3, 45-103.

KoNING, J.N. (1942) Over de ontwikkeling van den sinus urogenitalis en de accessoire geslachtsklieren van het varken. Thesis, Utrecht.

Marrable, A.W. (1971) The Embryonic Pig. Wheaton \& Co., Exeter.

Meusy-Dessolle, N. (1974) Evolution du taux de testosterone plasmatique au cours de la vie foetale chez le porc domestique. C. r. hebd. Séanc. Acad. Sci., Paris D 278, 1257-1260.

Meusy-Dessolle, N. (1975) Variations quantitatives de la testosterone plasmatique chez le porc mâle de la naissance à l'age adulte. C. r. hebd. Séanc. Acad. Sci., Paris $D$ 281, 1875-1878.

MoON, Y.S. \& HARDY, M.H. (1973) The early differentiation of the testis and interstitial cells in the fetal pig, and its duplication in organ culture. Am.J. Anat. 138, 253-268.

MOON, Y.S. \& RAESIDE, J.I. (1972) Histochemical studies on hydroxysteroid-dehydrogenase activity of fetal pig testes. Biol. Reprod. 7, 278-287.

RAEside, J.I. \& SigmaN, D.M. (1975) Testosterone levels in early fetal testes of domestic pigs. Biol. Reprod. 13, 318-321.

ReSKo, J.A., Feder, H.H. \& GoY, R.W. (1968) Androgen concentration in plasma and testis of developing rats. $J$. Endocr. 40, 485-491.

Ruokonen, A. \& Vihko, R. (1974) Steroid metabolism in testis tissue: concentrations of unconjugated and sulfated neutral steroids in boar testis. $J$. Steroid Biochem. 5, 33-38.

Segal, D.H. \& RAEside, J.I. (1975) Androgens in testes and adrenal glands of the fetal pig. J. Steroid Biochem. 6, 1439-1444.

StewarT, D.W. \& Raeside, J.I. (1976) Testosterone secretion by the early fetal pig testes in organ culture. Biol. Reprod. 15, 25-28.

van Straaten, H.W.M. \& Wensing, C.J.G. (1977) Histomorphometric aspects of testicular morphogenesis in the pig. Biol. Reprod. 17, 467-472.

van Straaten, H.W.M. \& Wensing. C.J.G. (1978) Leydig cell development in the testis of the pig. Biol. Reprod. 18, 86-93.

VerJans, H.L., CoOKe, B.A., DE JoNG, F.H., DE JoNG, C.M.M. \& VAN DER MOLEN, H.J. (1973) Evaluation of a radioimmunoassay for testosterone estimation. J. Steroid Biochem. 4, 665-676.

Wensing, C.J.G. (1973) Testicular descent in some domestic mammals. III. Search for the factors that regulate the gubernacular reaction. Proc. Kon. ned. Akad. Wet. C 76, 196-202.

Wrobel, K.H., Schilling, E. \& Dierichs, R. (1973) Enzyme histochemical studies on the porcine testicular interstitial cells during postnatal development. Histochemie 36, 321-333.

Received 21 December 1977 